\title{
Determination of Nitrate and Nitrite Contents of Syrian White Cheese
}

\section{Mohammad Amer Zamrik}

Department of Pharmacology and Toxicology, Faculty of Pharmacy, Damascus University, Damascus, Syria.

Email: zamrik-a@hotmail.com

Received January $9^{\text {th }}, 2013$; revised February $16^{\text {th }}, 2013$; accepted March $29^{\text {th }}, 2013$

Copyright (C) 2013 Mohammad Amer Zamrik. This is an open access article distributed under the Creative Commons Attribution License, which permits unrestricted use, distribution, and reproduction in any medium, provided the original work is properly cited.

\begin{abstract}
The levels of nitrate and nitrite were determined in 102 samples of Syrian white cheese which represents the major production of total cheeses, manufactured mainly from cow's milk and sheep's milk in a less degree. Determination of nitrate and nitrite levels has been made by spectrophotometric method. The results for nitrate in cow's and sheep's milk cheeses reveal an average of 5.10 and $6.25 \mathrm{mg} / \mathrm{kg}$, respectively. The results for nitrite in cow's and sheep's milk cheese were found to contain 1.24 and $1.31 \mathrm{mg} / \mathrm{kg}$ as an average, respectively. Several factors can play a role in the interpretation of the high nitrate content, such as livestock nutrition by forge with high nitrate load and water contaminated with nitrogen fertilizer and domestic effluents, primitive production techniques in many cases, and adding nitrate salts to prevent the growth of gas-producing bacteria caused by failing in the hygienic conditions. There is a necessity to apply strict controls to reduce the presence of these two anions in the Syrian white cheese.
\end{abstract}

Keywords: Nitrate; Nitrite; Copperized Cadmium Column; Syrian White Cheese (SWC)

\section{Introduction}

Despite the fact that all different kinds of cheese are considered as one of the important sources of food for humans, it may not be free from being a source of harmful elements, such as microbial contaminants, and the presence of different amounts of nitrate and nitrite.

The national academy of sciences (NAS) stated that vegetables provide $87 \%$ of nitrate in a normal diet, while the other products including fresh and cured meat and dairy provide the remainder [1].

Three general sources of the presence of nitrate and nitrite in cheese are:

First, nitrate can be found in raw milk and the loading, depending mainly on the quality of feed given to livestock (the level of nitrate in forges and water, especially if was polluted by nitrate) $[1,2]$. The presence of nitrate in cheese can occur naturally in the range of 1 to $8 \mathrm{mg} / \mathrm{kg}$, suffering from losing in the amount during the maturation and storage time $[3,4]$.

Second, because of the failure to achieve a good production environment within the proper hygienic conditions, a contamination by nitrate and nitrite sources could be happened at the technological process of cheese [4].

Third, by adding nitrate as a salt of potassium or so- dium or both, to cheese milk in order to prevent the growth of gas-producing bacteria, causing blowing (swelling) of the cheese as a result of the proliferation of coliforms, at the beginning of the maturation period and Clostridia butyricum and Clostridium tyrobutyricum, which cause late blowing. The procedure of adding this salt is practiced in some countries, especially in Europe [5-7].

The fresh white cheese is one of the sources of cheeses widespread in the countries of the north-east of the basin of the Mediterranean and the Balkans, which is produced in traditional methods without being subject to health surveillance [8].

Nitrate per se is relatively non-toxic to humans, and it toxicity attributed mainly to its reduction to nitrite [9].

Nitrate can be converted to nitrite through the mechanism of bacterial reduction as bio-transformation in the saliva and digestive system [10].

Moreover, the nitrite presented in stomach as a result of nitrate-nitrite contained food intake, may react with secondary and tertiary amines and amides to form $\mathrm{N}$ nitroso compounds (NOCs) include nitrosamines and nitroamides. N-nitroso compounds have carcinogenic potentiality [9-12]. Also, Nitrosation can occur during storage and ripening of the food product [13]. According to (Gray et al., 1979) nitrosamines were found in cheeses 
even without adding nitrate [14].

Furthermore, excessive intake of nitrate and nitrite in the diet may cause toxic effects associated with the formation of methaemoglobinaemia (Blue Baby Syndrome) which produced by oxidation of haemoglobin by nitrite. Infants are more susceptible to this syndrome [9-15].

Respecting to chronic effect of nitrate and nitrite, the IARC (2010), stated that, the JECFA (FAO/WHO expert committee on food additives) and SCF (The European Commission's, Scientific Committee on Food) set an ADI (Acceptable Daily Intake) for nitrate ion as 0 - 3.7 $\mathrm{mg} / \mathrm{kg}$ body weight per day (equivalent to $219 \mathrm{mg} /$ day for a $60 \mathrm{~kg}$ person), and the ADI for nitrite as $0-0.06$ $\mathrm{mg} / \mathrm{kg}$ of body weight per day (equivalent to $3.6 \mathrm{mg} /$ day for a $60 \mathrm{~kg}$ person) [16].

Due to the fact that the Syrian white cheese represents the major cheese kind consumed by Syrians, this research will focus on the quantitative determination of nitrate and nitrite contents in Syrian white cheese since those electrolytes can have an adverse impact to the consumer.

\section{Material and Methods}

\subsection{Samples Collection}

A total of 102 samples of Syrian white cheese (SWC) have been analyzed, 74 of the samples were produced from cow's milk, and the other 28 samples were produced from sheep's milk. Samples were obtained randomly from Damascus local and open markets in Syria. All samples were kept at $+4^{\circ} \mathrm{C}$. Analysis was conducted during three days of bringing the samples. The analyzing procedures were done from May to July 2012.

\subsection{Method of Analysis}

The extraction and determination procedures were based on the European standard EN ISO 14673-1:2004 (Milk and milk products-Determination of nitrate and nitrite contents) [17]. Initial preparation of the sample passed through five stages starting from grinding, weighing, dissolution in warm water, precipitation of the fat and proteins, ending with filtration.

The nitrate in a portion of filtrate was reduced to nitrite by means of copperized cadmium in a glass column. For the determination of nitrate in the reducing form (nitrite) and nitrite, sulphanilamide and N-1-naphtyl-ethylenediamide were used as coloring developing reagents. Measurement of the color intensity was made by Spectronic Genesys 2 spectrophotometer at a wavelength of $538 \mathrm{~nm}$, and compared with standard nitrite solutions. The method was continuously tested by standard addition of nitrate and nitrite. Recoveries have been found to be between the $98 \%$ and $102 \%$. The limit of detection was $0.34 \mathrm{ppm}$ for nitrate and $0.05 \mathrm{ppm}$ for nitrite. Analyses were run in duplicate. The results are expressed in $\mathrm{mg} / \mathrm{kg}$ of $\mathrm{NO}_{3}$ and $\mathrm{NO}_{2}$. All reagents were of analytical grade quality.

\subsection{Statistics}

(PASW Statistics 18) one way ANOVA test were conducted for statistical comparisons.

\section{Results}

In this study, nitrate and nitrite were determined in all cheese samples with a total of 102 samples of Syrian white cheese (SWC), 74 of the samples were produced from cow's milk and the other 28 samples were produced from sheep's milk.

Results for nitrate of all samples and for cow's and sheep's milk cheeses are presented separately in Table 1.

Nitrate content was found to be between ND - 34.88 $\mathrm{mg} / \mathrm{kg}$ in all types of cheese samples with $6.07 \mathrm{mg} / \mathrm{kg}$ as an average. (Nitrate was undetected in only two samples). The nitrate content in cow's milk cheese was found to be between ND - $30.18 \mathrm{mg} / \mathrm{kg}$ with $5.10 \mathrm{mg} / \mathrm{kg}$ as an average, while the nitrate content in sheep's milk cheese was found to be between ND - $34.88 \mathrm{mg} / \mathrm{kg}$ with $6.25 \mathrm{mg} / \mathrm{kg}$ as an average.

Table 2 represents the results for nitrite of all samples and for cow's and sheep's milk cheese separately.

Nitrite content was found between ND - $8.03 \mathrm{mg} / \mathrm{kg}$ in all types of cheese samples with $1.26 \mathrm{mg} / \mathrm{kg}$ as an average (nitrite was undetected in eight samples). The nitrite content in cow's cheese was found between ND - 8.03 $\mathrm{mg} / \mathrm{kg}$ with $1.24 \mathrm{mg} / \mathrm{kg}$ as an average, while the nitrite content in sheep's cheese was found between ND - 4.23 $\mathrm{mg} / \mathrm{kg}$ with $1.31 \mathrm{mg} / \mathrm{kg}$ as an average.

\section{Discussion}

In Syria, the white cheese which is a soft cheese type represents the major production of total cheeses manufactured from cow milk and sheep milk in a less degree [18]. The total production of cheeses in Syria, 2010 is 115,550 tonnes [19].

Most white Syrian cheese is made in non-licensed traditional means (Private small-scale processing facilities or in villages), and make up about $95 \%$ of the Syrian cheese industry. The other $5 \%-10 \%$ of the cheese milk is processed in big dairies, where the milk is pasteurized before processing [18].

According to Syrian cheeses specification, there is no legalization for nitrate acceptable limits in Syrian cheeses [20], but if we agree with the limits of nitrate in one of the Mediterranean country neighbor to Syria, and produce white cheese approximately in the same manner, the maximum permitted residual value for nitrate, according to Turkish food codex, 2002 is $10 \mathrm{mg} / \mathrm{kg}$ for cheese [21]. 
Table 1. The nitrate content $(\mathrm{mg} / \mathrm{kg})$ in SWC samples.

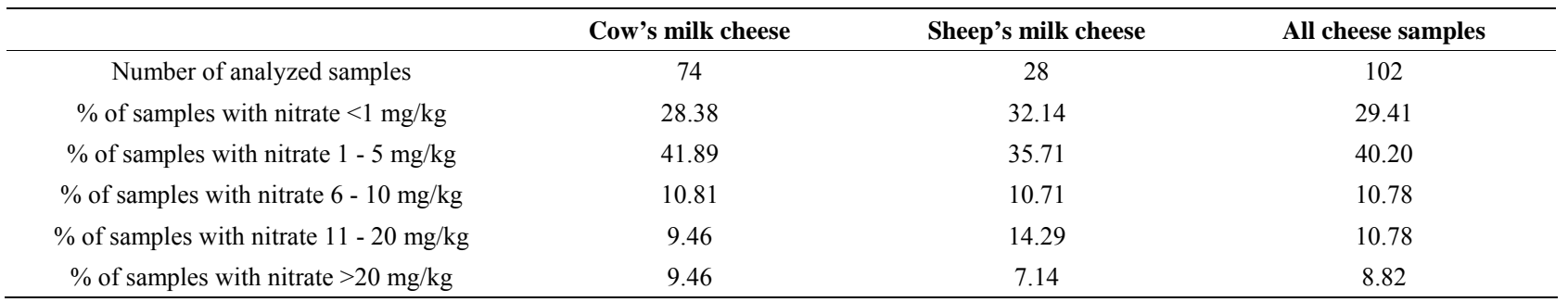

Table 2. The nitrite content (mg/kg) in SWC samples.

\begin{tabular}{ccc}
\hline & Cow's milk cheese & Sheep's milk cheese \\
\hline Number of analyzed samples & 74 & 28 \\
\% of samples with nitrate $<0.5 \mathrm{mg} / \mathrm{kg}$ & 51.35 & 42.86 \\
$\%$ of samples with nitrate $0.5-1 \mathrm{mg} / \mathrm{kg}$ & 21.62 & 14.29 \\
$\%$ of samples with nitrate $1.1-2 \mathrm{mg} / \mathrm{kg}$ & 9.46 & 17.86 \\
\% of samples with nitrate $>2 \mathrm{mg} / \mathrm{kg}$ & 17.57 & 25.00 \\
\hline
\end{tabular}

Considering the amount of $10 \mathrm{mg}$ nitrate $/ \mathrm{kg}$ cheese, as a maximum permitted limit, there are $19.6 \%$ of SWC as all studied cheeses, $18.92 \%$ of SWC produced from cow's cheese and $21.43 \%$ of SWC produced from sheep's cheese exceeding this limit.

Furthermore, the presence of nitrate in the extremities in raw milk may play a role in recording high values of nitrate. The primitive production techniques, and the failure in controlling the hygienic condition which may vary from one place to another, constitute the major reasons, where there are:

- Likelihood of accidental contamination by fertilizers sources in the facility.

- Using polluted water by nitrate resulting from the use of nitrogen fertilizer and domestic effluents in technological process [22].

- Intentionally added nitrates as preservative in order to retard bacterial growth potential, which can be caused by:

- Hand milking practice in many places [18].

- The presence of high percentage of moisture with different ratios of salt (The water content of white cheeses is higher than 55\%) [23].

- Most Syrian cheese suffers from lack of thermization treatment [18].

- In some cases, failure to achieve a proper hygienic environment for the manufactured cheeses during: storing, handling, and selling it in open market (on the sidewalk market).

It seems that the foregoing reasons may have been more influential on the content of nitrates in cheese made from sheep's milk than in cheese made from cow's milk as the comparing of the means was significant $p>0.05$.

The nitrite content in cheese samples were less than 1 $\mathrm{mg} / \mathrm{kg}$ in $57.15 \%$ of all samples. Eight of the analyzed samples were undetected for nitrite, in spite of the presence of nitrate in different concentrations; vice versa two of the analyzed samples, revealed no nitrate in spite of the presence of nitrite, this phenomenon can be attributed to the unstable nature of nitrites [24].

The nitrate and nitrite contents of different varieties of cheeses have been investigated in several countries. For instance, in Turkey, a study of Topçu et al. (2006), reported levels of nitrate and nitrite ranged between 0.92 $22.40 \mathrm{mg} / \mathrm{kg}$ for nitrate, and $0.88-1.64 \mathrm{mg} / \mathrm{kg}$ for nitrite in respect of white cheeses, while the levels of nitrate were ranged between $0.68-22.40 \mathrm{mg} / \mathrm{kg}$ for all varieties of cheese studied [25]. Also, the study of Buket et al. (2007), which dealt with Turkish white cheese showed ranges of $(0-24.02 \mathrm{mg} / \mathrm{kg})$ and $(0-2.88 \mathrm{mg} / \mathrm{kg})$ for nitrate and nitrite respectively [21]. Investigation of nitrate and nitrite in Romanian traditional cheese accomplished by Tudor et al. (2007), mentioned a range of (0.87 $17.52 \mathrm{mg} / \mathrm{kg})$ for nitrate and $(0.28-21.16 \mathrm{mg} / \mathrm{kg})$ for nitrite [4]. The research of Kyriakidis et al. (1998), for determination of nitrate and nitrite contents of Greek cheeses revealed a range of concentration $(0.7-13.1$ $\mathrm{mg} / \mathrm{kg})$ for nitrate and $(0.7-13.1 \mathrm{mg} / \mathrm{kg})$ for nitrite [1] Kirovska-Cigulevska (2002), determine nitrates in food product including cheeses in the republic of Macedonia ranged between $12.9-21.6 \mathrm{mg} / \mathrm{kg}$ in cow's milk cheese and $8.5-11.8 \mathrm{mg} / \mathrm{kg}$ in sheep's milk cheese [26].

In conclusion, the averages of nitrate and nitrite for the 102 studied samples were $6.067 \mathrm{mg} / \mathrm{kg}$ and 1.256 $\mathrm{mg} / \mathrm{kg}$, respectively. The percentage of nitrate concentration exceeding $10 \mathrm{mg} / \mathrm{kg}$ was $19.60 \%$. Including that there is no effective control of production processes of white cheeses, the presence of nitrate, with concentration higher than $10 \mathrm{mg} / \mathrm{kg}$, may returns to poor hygienic condition, primitive production technique and adding nitrate 
to the cheese milk.

Although the intake of nitrate and nitrite attributable to eaten cheese form a small percentage ratio of the whole amounts intake by food, we cannot neglect the role that can be played by these compounds as precursors to product the carcinogenic N-nitroso compounds. According to Gloria et al. (1997), a positive correlation was observed between the level of nitrate added to cheese milk and the levels of N-nitrosodimethylamine and N-nitrosodiethylamine in the studied cheeses [27].

Finally, if we cannot abolition the natural presence of nitrate and nitrite in cheese milk, we can apply strict controls aimed at curbing excesses in concentrations with emphasis on the need for a legislation that sets the maximum acceptable limits for nitrate and nitrite in the Syrian cheese, similar to many of the countries of the world.

\section{REFERENCES}

[1] N. B. Kyriakidis, K. T. Georgiou and E. Tsani-Batzaka, "Nitrate and Nitrite Content of Greek Cheeses," Journal of Food Composition and Analysis, Vol. 10, No. 4, 2007, pp. 343-349. doi:10.1006/jfca.1997.0549

[2] M. Baranová, P. Mal'a and O. Burdová, "Transport of Nitrates and Nitrites into the Milk of Dairy Cows through the Digestive System," Veterinary Medicine, Vol. 38, No. 10, 1993, pp. 581- 588 (Article in Slovak].

[3] E. Renner, "Nutritional Aspects of Cheese," In: P. F. Fox, Ed., Cheese: Chemistry, Physics and Microbiology, 2nd Edition, Vol. 1, Aspen Publishers, Frederick, 1999, pp. 557- 579.

[4] L. Tudor, E. Mitrănescu, L. Tudor and F. Furnaris, "Assessment of Nitrate and Nitrite Content of Romanian Traditional Cheese," Lucrari Stiintifice, Universitatea de Stiinte Agricole a Banatului Timisoara, Medicina Veterinara, Vol. 40, 2007, pp. 694-699.

[5] K. Glass and M. E. Doyle, "Safety of Processed Cheese," A. Review of the Scientific Literature, Food Research Institute, University of Wisconsin, Madison, 2005.

[6] B. Koréneková, J. Kottferová and M. Korének, "The Fate of Added Nitrate Used in the Manufacture of Emmental Cheese," Food Additives \& Contaminants, Vol. 17, No. 5, 2000, pp. 373-377. doi:10.1080/026520300404770

[7] P. Walstra, A. Noomen and T. J. Geurts "Dutch-Type Varieties," In: P. F. Fox, Ed., Cheese: Chemistry, Physics and Microbiology, 2nd Edition, Vol. 2, Aspen Publishers, Frederick, 1999, pp. 39-82.

[8] T. Binitis and P. Papademas, "Microbiological Quality of White Brined Cheeses: A Review," International Journal of Dairy Technology, Vol. 55, No. 3, 2002, pp. 113-120. doi:10.1046/j.1471-0307.2002.00054.x

[9] European Food Safety Authority (EFSA), "Nitrate in Vegetables Scientific Opinion of the Panel on Contaminant in the Food Chain," The EFSA Journal, Vol. 69, 2008, pp. 1-79.

[10] S.-T. Du, Y.-S. Zhang and X.-Y. Lin, "Accumulation of Nitrate in Vegetables and Its Possible Implications to
Human," Agricultural Sciences in China, Vol. 6, No. 10, 2007, pp. 1246-1255.

doi:10.1016/S1671-2927(07)60169-2

[11] P. Santamaria, "Review-Nitrate in Vegetables: Toxicity Content, Intake and EC Regulation," Journal of the Science of Food and Agriculture, Vol. 86, No. 1, 2006, pp. 10-17. doi:10.1002/jsfa.2351

[12] G. J. A. Speijers and P. A. Van den Brandt, "Nitrite and Potential Endogenous Formation of N-Nitroso Compounds," In: WHO Food Additives Series 50, World Health Organization, Geneva, 2003.

[13] R. Walker, "Nitrates, Nitrites and N-Nitrosocompounds: A Review of the Occurrence in Food and Diet and the Toxicological Implications," Food Additives and Contaminants, Vol. 7, No. 6, 1990, pp. 717-768. doi:10.1080/02652039009373938

[14] J. I. Gray, D. M. Irvine and Y. Kakuda, "Nitrates and Nnitrosamines in Cheese," Journal of Food Protection, Vol. 42, No. 3, 1979, pp. 263-272.

[15] Toxicity and Exposure Assessment for Children's Health, (TEACH Chemical Summary), "Nitrates and Nitrites," US EPA, 2007.

[16] International Agency for Research on Cancer (IARC), "Monographs on the Evaluation of Carcinogenic Risks to Humans - Ingested Nitrate and Nitrite and Cyanobacterial Peptide Toxins," Vol. 94, WHO, Geneva, 2010.

[17] EN ISO-14673-1, "Milk and Milk Products-Determination of Nitrate and Nitrite Contents," International Organization for Standardization, 2004.

[18] FAO, "Milk and Dairy Products, Post-Harvest Losses and Food Safety in Sub-Sahran Africa and the Near East: A Review of the Small Scale Dairy Sector-The Syrian Arab Republic," FAO, Rome, 2003.

[19] Syrian Group of Agricultural Statistics, "Ministry of Agriculture and Agrarian Reform," 2010 [Document in Arabic].

[20] Syrian Arab Standards and Metrology Organization (SASMO), "Syrian Cheeses Specification," No. 289, Syrian Arab Standards and Metrology Organization, Damascus, 2002.

[21] E. R. Buket, B. O. Aysel and Y. Gülderen, "The Determination of Nitrate and Nitrite Levels in Turkish White Cheese Samples Consumed in Ankara Region," Gida Dergisi, Vol. 33, No. 4, 2008, pp. 53 -157.

[22] M. A. Zamrik, "A Study about the Anionic Compounds in Drinking Water in Kalamoon," Arab Journal of Pharmaceutical Sciences, Journal of the Association of Arab Universities, Vol. 3, No. 5, 2007, pp. 97-108.

[23] SCVMPH, "Opinion of the Scientific Committee on Veterinary Measures Relating to Public Health on Staphylococcal Enterotoxins in Milk Products, Particularly Cheeses," SCVMPH, 2003.

[24] T. Hambridge, "Nitrate and Nitrite: Intake Assessment," In: WHO Food Additives Series 50, World Health Organization, Geneva, 2003.

[25] A. Topçu, A. A. Topçu, I. Saldamli and M. Yurttagül, "Determination of Nitrate and Nitrite Content of Turkish Cheeses," African Journal of Biotechnology, Vol. 5, No. 
15, 2006, pp. 1411-1414.

[26] O. Kirovska-Cigulevska, "Determination of Nitrates in Food Products," Balıkesir Üniversitesi Fen Bilimleri Enstitüsü Dergisi, Vol. 4, No. 2, 2002, pp. 70-73.

[27] M. B. A. Gloria, S. R. Vale, O. L. Vargas, J. F. Barbour and R. A. Scanlan, "Influence of Nitrate Levels Added to Cheesemilk on Nitrate, Nitrite and Volatile Nitrosamine Contents in Gruyere Cheese," Journal of Agricultural and Food Chemistry, Vol. 45, No. 9, 1997, pp. 3577-3579. doi:10.1021/jf970203f 